SZEMLE

\title{
Adventív Fallopia taxonok botanikai, fitokémiai és gyógyászati jellemzése
}

\author{
BÉKÉSINÉ KALLENBERGER Heléna ${ }^{1}$, HORVÁTH Györgyi ${ }^{1}$, BALOGH Lajos², \\ BALÁZS Viktória Lilla ${ }^{3}$ és PAPP Nóra ${ }^{1 *}$
}

\begin{abstract}
${ }^{1}$ PTE ÁOK Farmakognóziai Intézet, 7624 Pécs, Rókus u. 2.; kallenberger@gmail.com, gyorgyi.horvath@aok.pte.hu, *nora4595@gamma.ttk.pte.hu

${ }^{2}$ Savaria Múzeum, Természettudományi Osztály, 9701 Szombathely, Kisfaludy S. u. 9.; balogh.lajos@savariamuseum.hu

${ }^{3}$ PTE TTK Biológiai Intézet, 7624 Pécs, Ifjúság u. 6.; balazsviktorialilla@gmail.com
\end{abstract}

Elfogadva: 2016. január 18.

Kulcsszavak: etnobotanika, Fallopia, fitokémia, morfológia, rendszertan, szövettan.

Összefoglalás: A Fallopia sectio Reynoutria (óriáskeserűfü) fajok kelet-ázsiai eredetủek, de napjainkban a világ számos pontján előfordulnak. Európába a 19. században dísznövényként kerültek be egyes fajok. Fő hatóanyagaik között cserzőanyagok, fenolkarbonsavak, flavonoidok, stilbének (pl. rezveratrol) és antrakinonok (p. emodin) említhetők, amelyek számos élettani hatással és gyógyászati jelentőséggel is rendelkeznek. A tradicionális kínai és japán medicina egyes fajok rizómáját hepatitis, magas vérnyomás, bőrsérülések és vérzés ellen alkalmazza. Napjainkban számos vizsgálat igazolja a növények baktérium- és gombaölö, antioxidáns, citotoxikus, neuroprotektív, koleszterinszint- és gyulladáscsökkentő hatását, továbbá rákterápiában való alkalmazásukra is rendelkezésre állnak adatok. Egyes taxonok nehézfémkötő szereppel és allelopátiás hatással is jellemezhetők, míg mások takarmányként való termesztésére folynak kísérletek. Kiemelendő a fajok energianövényként való alkalmazása is, amely magas fütőértékükkel áll összefüggésben. Ezek az eredmények további ökológiai, fitokémiai és hatástani vizsgálatok lehetőségét vetítik előre, amelyek a nemzetség számos potenciális felhasználási területére irányítják a figyelmet. Összefoglalónkban a japán ( $F$. japonica), a szahalini $(F$. sachalinensis) és Európában keletkezett hibridjük, a cseh óriáskeserüfü ( $F$. × bohemica) történeti, etnobotanikai, morfológiai, hisztológiai, fő fitokémiai, népgyógyászati, valamint gyógyászati jelentőségét tekintjük át.

\section{Bevezetés}

Az ázsiai eredetű Fallopia japonica (Houtt.) L. P. Ronse Decr. (japán óriáske serüfü) és $F$. sachalinensis (F. Schmidt) L. P. Ronse Decr. (szahalini óriás- 
keserüfü) fajokat a 19. században mint dísznövényeket hozták be Európába (Townsend 1997, BARney et al. 2006, TiÉBRÉ et al. 2007). A japán és kisebb mértékben a szahalini óriáskeserủfüvet a transzformer inváziós növények között tartják számon, amelyek képesek átalakítani az ökoszisztémát mind szerkezeti, mind kémiai szempontból (Forman és KESSELI 2003, AgUilera et al. 2010); a japán óriáskeserüfüvet a világ száz leginkább inváziós növényfaja közé sorolták (Grimsby et al. 2007). A cseh óriáskeserüfü (F. × bohemica (Chrtek \& Chrtková) J. P. Bailey) a japán és a szahalini óriáskeserüfü hibridnövénye (BARNEY et al. 2006, HROMÁd Ková et al. 2010), amelyet először Csehországban írtak le 1983ban (KovÁRovÁ et al. 2010).

Jelen munkánkban a 3 taxon legfontosabb etnobotanikai, történeti, taxonómiai, morfológiai, szövettani, fitokémiai, népgyógyászati és gyógyászati szerepét jellemezzük. Élőhelyüket tekintve kiemeljük eredeti előfordulásukat, valamint európai és hazai elterjedésüket napjainkban.

\section{Rendszertani jellemzők, nevezéktan}

A Fallopia fajok a Magnoliophyta törzs Rosophytina altörzsébe, a Rosopsida osztály Caryophyllidae alosztályába, a Polygonanae förenden belül a keserüfüvirágúak rendjébe (Polygonales) és a keserüfüfélék családjába (Polygonaceae) sorolhatók (BALOGH 2009). A Polygonales rendbe többnyire lágyszárú növények tartoznak, de a trópusokon fás nemzetségek is megtalálhatók. Egyetlen családja a keserüfüfélék (Polygonaceae) (BoRHIDI 1998), amely mintegy negyven nemzetséget tartalmaz (BALOGH 2004).

A fajok taxonómiája és nevezéktana az idők folyamán sokat változott, amely részben felfedezésük történetének is tulajdonítható. A japán óriáskeserüfüvet először Houttuyn írta le 1777-ben Reynoutria japonica néven japán anyagból. 1846ban további példányokat gyűjtöttek be Japánból, amelyeket Siebold és Zuccarini Polygonum cuspidatum-nak nevezett el. Csak 1901-ben fedezték fel, hogy a két taxon azonos (BEERLING et al. 1994).

A legújabb kutatások alapján a régebben Reynoutria, Polygonum, Tiniaria, Pleuropterus és részben Bilderdykia nemzetségekbe is sorolt taxonokat egy tágabban értelmezett Fallopia (s. 1.) nemzetségben tárgyalják, amelyet négy szekcióra (Fallopia, Parogonum, Sarmentosae, Reynoutria) osztanak. Ezek közül hazánkban a Sarmentosae szekcióba tartozó tatáriszalag (F. baldschuanica (Regel) J. Holub) és a kínai iszalag ( $F$ aubertii (L. Henry) J. Holub) fordulnak elö, amelyek évelő, fás kúszónövények, valamint a Fallopia szekcióba tartozó egyéves, kapaszkodó szárú sövénykeserüfü ( $F$. dumetorum (L.) J. Holub) és a szulákkeserüfü ( $F$. convolvulus (L.) A. Löve) (BALOGH 2004, 2009). 
Az általunk vizsgált három faj a japán ( $F$. japonica), a szahalini ( $F$. sachalinensis) és a cseh óriáskeserüfü ( $F$. $\times$ bohemica), amelyek a Fallopia nemzetség Reynoutria szekciójába tartoznak (BALOGH 2004). A nemzetség nevét a páduai botanikus kert felügyelőjéről, Gabriello Fallopióról, avagy Fallopiusról kapta, akit a modern anatómia egyik alapítójának is tekintenek (MOLNÁR 2009).

\section{Elterjedés, élőhelyi jellemzők}

A Fallopia japonica Japánban, Dél-Szahalinon, a déli Kuril-szigeteken, Koreában, Közép-Kelet Kínában és Tajvanon honos, de napjainkra egész Európában, az Egyesült Államokban és Magyarországon is elterjedt (BALOGH 2008, HollingsWORTH és BAILEY 2000). Szinantróp elterjedési területe több földrészre is kiterjed. Európába 1823-ban hozták be. Napjainkra kontinensünk nagy területein elterjedt, északon az é. sz. $70^{\circ}$-ig, míg délen csak a Mediterráneumban nem fordul elő. A Kárpát-medencéből először 1923-ban jelezték elvadulását, jelenleg minden országában jelen van. Európán kívül özönnövény Észak-Amerika területén (Mexikóban nem) és Új-Zélandon (Hollingsworth és BAIley 2000, BAlogh 2008). A $F$. japonica magyarországi előfordulásáról az 1920-as évektől vannak adatok, a 20. század végére országszerte meghonosodottnak jelezték, különösen az Északiközéphegységben és a Dunántúlon. Valószínűleg azonban legalább nagyságrenddel kisebb mértékben lehet jelen, mivel adatainak túlnyomó többsége a hibridfajra vonatkozhat. Szórványos előfordulása egykori ültetési környezetében jellemző, elsősorban települési ruderális élőhelyeken (BALOGH 2008). A Fallopia sachalinensis a déli Kuril-szigeteken, Dél-Szahalinon, Japán északi és középső részén honos (Marigo és Pautou 1998, Balogh 2008, Hromád ková et al. 2010), Európában sokkal ritkábban fordul elő. Szinantróp elterjedési területe szűkebb, mint a társfajé. Európába 1863-ban hozták be, ahol sokfelé meghonosodott, de jóval ritkább. Elterjedésének súlypontja kontinensünk északnyugati és Közép-Európa északi része. Az é. sz. $45^{\circ}$-tól délre csak Bulgáriából ismert. Szigetszerűen előfordul a Skandináv-félsziget déli részein (é. sz. $65^{\circ}$-ig), a balti államokban, Ukrajnában és Oroszországban is. Európán kívül Észak-Amerikából, Új-Zélandról, Ausztráliából és Dél-Afrikából jelezték szubspontán előfordulását. A Kárpát-medencében csak néhány szórványos adata van Ausztriából, Szlovákiából és Romániából (MARIGO és PAutou 1998, BAlogh 2008, Hromádková et al. 2010). A F. sachalinensis hazai jelenlétének ismerete is félreismert példányokon nyugodott, korábbi adatai minden bizonnyal az akkor még le nem írt - számos bélyegében hasonló - hibridfajra vonatkozhattak. Magyarországon a legutóbbi időkig csak botanikus kerti jelenléte volt biztos (BALOGH 2008). Napjainkban három bizonyított előfordulása van, kettő erdei ruderális élőhelyen (Gerecse 2006, Vendvidék 2010), egy pedig 
Baranya megyében, patak menti, zavart élőhelyen, amelyet terepi munkánk során fedeztünk fel 2012-ben. Az állomány a Pellérd községet Pécs várossal összekötő kerékpárút mentén található (földrajzi koordináták: É. sz. 46³' 6.35”, K. h. $\left.18^{\circ} 11^{\prime} 52.38^{\prime \prime}\right)$. A Fallopia $\times$ bohemica a szülőfajok hazájából nem ismert. A fenti két faj kereszteződésével Európában jött létre, 1983-ban írták le Csehországban (KovÁrová et al. 2010). Bár elterjedtségének kutatottsága még nem kielégítő, biztosan jelen van Ausztráliában, Nyugat-, Észak- és Közép-Európában, keleten Lengyelország-Ukrajna-Balkán-félsziget térségéig, ugyanakkor nincs még adata a Mediterráneumból. A F. ×bohemica magyarországi jelenlétét 1998-ban igazolták. Hazánkban leggyakrabban funkcionálisan hímivarú, termést gyakorlatilag nem érlelő állományaival találkozhatunk. Előfordulása elsősorban zavart élőhelyeken, folyóvizek mentén, ártereken, erdőszéleken, ruderáliákon jellemző országszerte, de föleg a dombvidéki tájakon (BALOGH 2008, 2012).

\section{Életmenet}

A Fallopia japonica, F. sachalinensis és $F$. × bohemica a hazai flóra legmagasabb, többször virágzó, évelő, lágy szárú növényei. Gyors tavaszi hajtásnövekedésük a tövükön és fásodó rizómájukon áttelelő rügyekből indul március-április fordulóján. A sűrü állású, fásodó tövű főszárakat követően fejlődnek ki az oldalhajtások. A virágzás július második felétől szeptemberig-októberig tart. A virágok túlnyomórészt entomogámok. A termések - ahol képződnek - szeptember-októberben érnek be, majd október-novemberben hullanak el. Szárnyas makkocska termésük hazájukban anemochor. Európában azonban elsősorban nem generatív, hanem vegetatív módon terjednek. Kúszó rizómáikkal a talajt behálózva folyamatosan növekvő polikormonokat képeznek. Az új állományok létrejöttére alkalmas propagulumok (rizóma-, ritkábban hajtásrészek) föleg antropochoria és hidrochoria útján terjednek. A lombhullás október végétől, de legkésőbb a fagyok nyomán következik be, amelyeknek hatására a szár is elhal. A fajok regenerációs képessége kiváló: könnyen megújulnak rizómadarabokból, de olykor szárdarabokból is, ami terjedésüket nagymértékben elősegíti (BALOGH 2012).

\section{Fogyasztók és kórokozók}

\section{Herbivorok}

A Fallopia japonica leveleit károsító fogyasztó szervezetek Japánban különböző levélbogarak, pl. simahátú csillagoscincér (Anoplophora glabripennis), lepkék és levéldarazsak, de levéltetvek és különböző rozsdagombák is csökkentik az ép levéllemez felületét. Szárát a benne fejlődő lárvák, rizómáját a japán gyökér- 
rágó lepke (Endoclita excrescens) lárvái lyuggatják (BAILEY 2003). Európai megfigyelések szerint a növény szárát az emlősök közül a juh, szarvasmarha, kecske, ló és szamár lelegeli, termését a házi veréb elfogyasztja, míg a rizóma egyes haszonállatok számára mérgező. Az ízeltlábúak közül atka (Tetranychus urticae) és néhány rovar táplálkozik rajta, így egyes medve-, araszoló-, bagoly- és tarkalepkék, valamint néhány ormányos- és levélbogárfaj (részleteiben vö. BEERLING et al. 1994, BALOGH 2004, 2008).

A Fallopia sachalinensis esetében Európában egy polifág medvelepkefajt (Spilarctia lutea) és egy levéltetüt mutattak ki a növényről.

A Fallopia $\times$ bohemica herbivóriájára az említett medvelepkefajon kívül egyegy oligofág levélbogár, illetve kétszárnyú, továbbá atkák kártételére vonatkozóan ismeretesek németországi adatok (ZIMMERMANN és TopP 1991).

\section{Patogének}

A Fallopia japonica esetében parazita gombákat nem találtak. A kórokozó szaprotróf gombák közül a növényen több tömlős-, bazídiumos és konídiumos gombát, valamint számos plurivor mikrogombát azonosítottak a növekvő és elhalt szárakról.

A Fallopia sachalinensis száráról és leveléről jelzett néhány szaprotróf gomba a tömlös- és konídiumos gombák közé tartozik.

A Fallopia $\times$ bohemica esetében nincs erre vonatkozó adat (BEERLING et al. 1994, BALOGH 2004, 2008).

\section{Morfológiai jellemzők}

A Fallopia fajok lágy, felálló szárú, gyöktörzses évelők (BALOGH 2009). Általában 2-3 méter magasra is megnőnek, 1-2 méter mélyre hatoló gyökerekkel és oldalirányban messze kúszó, rügyeket tartalmazó rizómákkal rendelkeznek (BALOGH 2004). Vastag, felálló száruk alul üreges, legalul lomblevél nélküli; leveleik nagyok, széles vagy megnyúlt tojásdadok, ép szélűek, többé-kevésbé kihegyezettek (BEERLING et al. 1994, Kim és PARK 2000). Változatos alakúak és méretủek: a főhajtáson levők a legnagyobbak és szórt állásúak, míg az oldalhajtásokon találhatók jóval kisebbek és váltakozók (BALOGH 2004). A krémfehér színű virágok összetett bugavirágzatot alkotnak (BEERLING et al. 1994). Kétlakiak (ritkán felemás virágúak, poligámok), amely ivari kétalakúságot is jelent (BALOGH 2004). A porzók száma 8; a bibék rojtosak, amelyek három szabadállású bibeszálon helyezkednek el (TIÉBRÉ et al. 2007).

A hímivarú növényegyedeken a termőtáj, míg a nőivarú példányokon a porzók csökevényesek (kivéve a $F$. ×bohemica esetében, ahol a hímivarú egyedeken 
hermafrodita virágok is képződhetnek, esetükben azonban mégsem fejlődnek termések). A $F$. sachalinensis hímivarú példányain megjelenhetnek termések, mert ott a termőtáj csak részben csökevényes. E kivételtől eltekintve a $10 \mathrm{~mm}$ hosszú, lepelbe zárt, háromélü, illetve -szárnyú makkocska termések csak nőivarú példányokon képződnek. A $F$. japonica esetében a makk 2,5 mm hosszú (BALOGH 2004).

A megkülönböztető bélyegeket tekintve (BARNEY et al. 2006) a $F$. japonica alkalmanként $2 \mathrm{~m}$-nél magasabbra is nőhet, míg a $F$. ×bohemica akár a $4,5 \mathrm{~m}$ feletti magasságot is elérheti (BALOGH 2008). A F. sachalinensis Európában képes 4-5 m-ig vagy annál nagyobbra is nőni (Hrom ÁD KovÁ et al. 2010). A F. japonica levelei kemények és bőrneműek, míg a $F$. sachalinensis-é lágyak, a $F$. $\times$ bohemica pedig köztes szövetü levelekkel rendelkezik (BALOGH 2008). Méretüket illetően a $F$. japonica esetében ismertek a legkisebb levelek (8-15 cm hosszúak és 5-12 cm szélesek) (BEERLING et al. 1994, BARNEY et al. 2006) összehasonlítva a $F$. sachalinensis $30 \mathrm{~cm}$-nél hosszabb és a $F$. $\times$ bohemica köztes méretủ leveleivel (10$23 \mathrm{~cm}$ hosszúak és 9-20 cm szélesek) (BALOGH 2008).

Ezen jellemzőkön kívül a középső szárlevelek a leginkább alkalmasak a vizsgált fajok azonosítására és megkülönböztetésre (1. ábra). A $F$. japonica esetében a levelek széles tojásdadok, a levélváll egyenesen vagy tompa ék alakban levágott
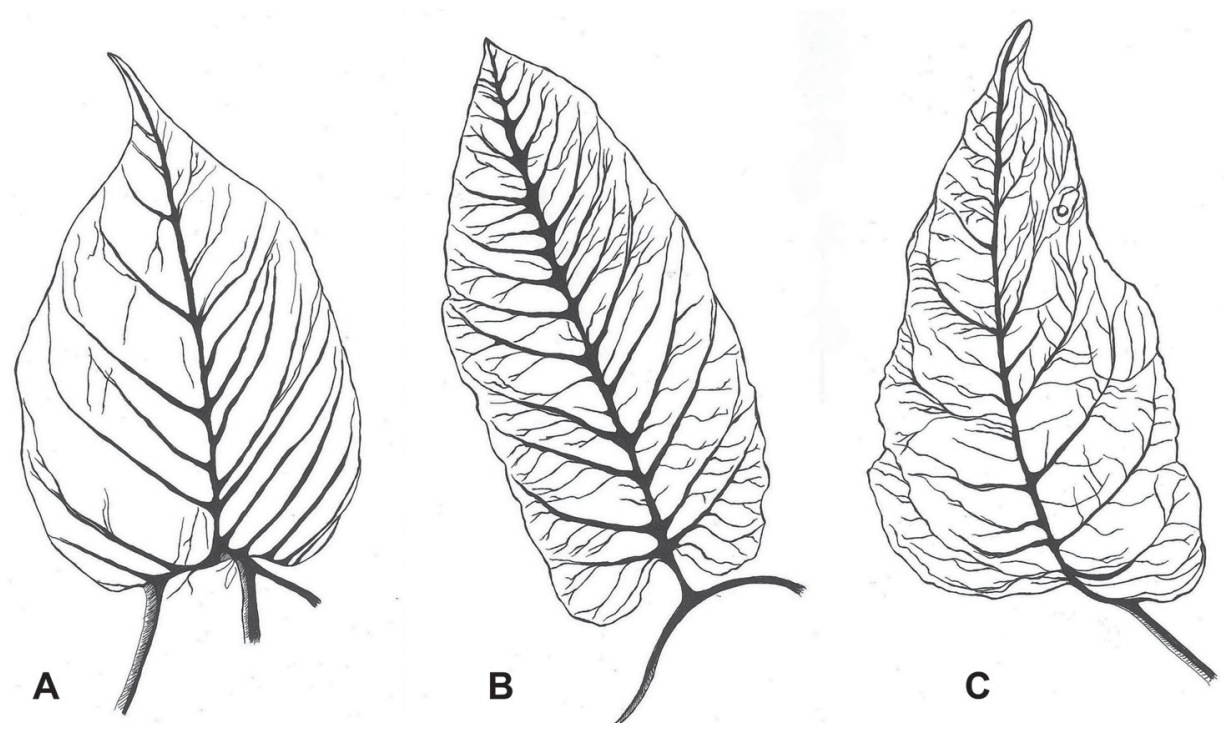

1. ábra. A vizsgált Fallopia fajok leveleinek morfológiai összehasonlítása. $\mathrm{A}=$ F. japonica; $\mathrm{B}=F$. sachalinensis; $\mathrm{C}=F$. $\times$ bohemica. (rajz: Kallenberger Melinda)

Fig. 1. Morphological comparison of the leaves of the studied Fallopia species. $\mathrm{A}=$ F. japonica; $\mathrm{B}=$ F. sachalinensis; $\mathrm{C}=$ F. $\times$ bohemica. (drawing: Melinda Kallenberger) 
(BARNEY et al. 2006), a levélcsúcs hirtelen kihegyezett (BEERLING et al. 1994). A F. sachalinensis levelei hosszúkás-tojásdadok, hegyesek vagy tompa hegyủek, és szíves vállúak (TIÉBRÉ et al. 2007, BALOGH 2008). A F. × bohemica széles tojásdad és kihegyezett középső szárlevelekkel jellemezhető, a felső leveleken egyenesen vagy tompa ék alakban levágott, az alsó leveleken kissé szíves levélvállal (BALOGH 2008).

A fenti bélyegek mellett a lombleveleken elhelyezkedő trichómák jelenléte vagy hiánya szintén fontos határozóbélyeg (CHEN et al. 2013), amelyeket a szövettani jellemzőknél tárgyalunk részletesebben.

\section{Szövettani jellemzők}

A Fallopia japonica levelei kopaszok, kivéve az elsőrendű erek fonáki részén, ahol nagyítóval is alig látható egysejtű papillák találhatók. Ezzel szemben a $F$. sachalinensis leveleinek fonáki oldala szabad szemmel is jól láthatóan szőrözött, főleg az ereken, de az érközökben is. Ezek a fedöszőrök 4-12 sejtesek, 0,2-0,6 mm hosszúak. A $F$. ×bohemica fonáki oldala szabad szemmel kopasznak látszik, csak nagyítóval figyelhetők meg ritkásan rövid szőrök inkább az ereken, míg az érközök majdnem kopaszok. Itt a szörök 1-4 sejtesek, 0,2 mm-nél rövidebbek (BALOGH 2008, 2009). A nemzetségbe tartozó taxonok egyes szerveinek szövettanára vonatkozó szakirodalmat nem találtunk, ezért megvizsgáltuk az ide tartozó három kijelölt faj lomblevelének, levélnyelének és hajtásának hisztológiai bélyegeit. A vizsgált szövettani bélyegeket tekintve a 3 faj számos tulajdonságban hasonlóságot mutat. A szárban mindhárom fajnál kollaterális nyílt nyalábok figyelhetők meg, amelyek koncentrikus körben helyezkednek el. A heterogén mezofillumú, dorziventrális levelekben mindegyik faj esetében oszlopos és szivacsos sejtek, intercelluláris járatok, kollaterális zárt nyalábok, illetve buzogányfej-alakú (rozetta) kalcium-oxalát kristályok találhatók. A mezomorf sztómák a levelek fonáki oldalán helyezkednek el (hiposztomatikus levél). Az epidermiszsejtek a levélen anizodiametrikusak, az oszlopos sejtek háromszor olyan hosszúak, mint szélesek, a szivacsos sejtek hosszúsága és szélessége pedig közel azonos (izodiametrikusak). A fajok levélnyelében egy nagy központi és több kisebb szállítónyaláb figyelhető meg (BÉKÉSI-KALLENBERGER et al. 2012).

\section{Fitokémiai jellemzők}

Az óriáskeserüfü fajok különböző részeiben számos biológiai szempontból aktív anyagot azonosítottak. A lomblevelek metanolos kivonatai föként katechint, epikatechint, klorogénsavat, kávésavat és kvercetin-származékokat tartalmaznak (HromÁD KovÁ et al. 2010). A Fallopia japonica esetében stilbéneket (rezveratrol és piceid), azok glikozidjait, valamint antrakinonokat (emodin, fiszcion, antra- 
<smiles>Cc1cc(O)c2c(c1)C(=O)c1cc(O)cc(O)c1C2=O</smiles>

1<smiles>Oc1ccc(/C=C/c2cc(O)cc(O)c2)cc1</smiles><smiles>COc1cc(O)c2c(c1)C(=O)c1cc(C)cc(O)c1C2=O</smiles><smiles>Oc1cc(O)c2c(c1)OC(c1ccc(O)c(O)c1)[C@H](O)C2</smiles><smiles>OCC1C(O)C(O)C(Oc2cc(O)cc(/C=C/c3ccc(O)cc3)c2)C1O</smiles>

2.ábra. A Fallopia fajokban előforduló fő hatóanyagok szerkezeti képlete. $1=$ emodin; 2 = fiszcion; $3=$ katechin $4=$ rezveratrol; $5=$ polidatin

Fig. 2. Chemical structure of the main compounds of Fallopia species $1=$ emodin; $2=$ physcion; $3=$ catechin $4=$ resveratrol $; 5=$ polydatin

glikozid B) azonosítottak (2. ábra) (BEERLING et al. 1994, Yi et al. 2007, QIAN et al. 2008, KovÁrová et al. 2010, Kovárová et al. 2011, Shen et al. 2011, Peng et al. 2013, Chen et al. 2013, FrantíK et al. 2013, BÉKÉSi-Kallenberger et al. 2013). A levelek és a szár flavonoidokat, flavonolokat és antociánokat tartalmaznak (Beerling et al. 1994, Murai et al. 2015). A F. sachalinensis Mizutani (1996) szerint terpenoid: triterpén (szterol), valamint fenoloid: tannin, flavonoid (kvercetin-glikozid) és emodin vegyületeket tartalmaz (SzABó 1997).

\section{Kromoszómaszám}

Citogenetikai adatokat a következő fajok és hibridek esetében írtak le: Fallopia japonica var. japonica (oktoploid, $2 \mathrm{n}=88) ; F$. japonica var. compacta $(2 \mathrm{n}=$ 44, tetraploid), F. sachalinensis (tetraploid, $2 \mathrm{n}=44$; ez kevésbé elterjedt, mint a $F$. japonica). A $F$. ×bohemica változó ploiditási szinttel jellemezhető a tetraploidtól az oktoploidig (BAILEY 2003, BímovÁ et al. 2003). A hibridek között említhető a $2 \mathrm{n}=66$ kromoszómaszámú, amely a $F$. japonica var. japonica $(2 \mathrm{n}=88)$ és a $F$. sachalinensis $(2 \mathrm{n}=44)$, a $2 \mathrm{n}=44$ kromoszómaszámú, amely a $F$. japonica var. compacta $[2 \mathrm{n}=44]$ és $F$. sachalinensis $(2 \mathrm{n}=44)$ kereszteződéséből keletkezik (TiÉbré et al. 2007, Jeong és PARK 2000). 


\section{Történeti és etnobotanikai adatok}

A japán és a szahalini óriáskeserüfü a 19. század első, illetve második felében kerültek be Európa nyugati részébe. A Fallopia japonica-t nemcsak impozáns megjelenése miatt ültették, mint dísznövényt, hanem dús zöldhozama miatt helyenként szántóföldi takarmányként vagy világos erdőkben és erdőszéleken vadtakarmányként is termesztésbe vonták. Ezt követően gyakorta elvadult, majd egyre több helyütt honosodott meg (BALOGH 2004). Így a 20. század folyamán populációi betörtek a Brit területek nagy részére (MARIGO és PAUTOU 1998). Már Hegi (1910) is számos esetben említi a közép-európai meghonosodását (Rajnavidék, Vesztfália, Poroszország, Bajorország, Csehország, Szlovákia, Ausztria, Svájc). Beszámolt például egy potsdami kertész szándékos ültetésről is 1861-ben Helgoland homokdűnéin, ahol a növényt a homokos talaj megkötésére használták (vö. BEERLING et al. 1994). Csehországban azóta elterjedésének negatív hatását mutatták ki egyes madárfajok élőhelyét tekintve (HAJZERová és REIF 2014). Később a másik faj, a $F$. sachalinensis széleskörü elterjedését is megfigyelték Németországban, majd Franciaországban is (MARIgo és PAUTOU 1998, GERBER et al. 2008). Napjainkra az óriáskeserüfü-fajok már Kelet-Európában is elterjedt özönnövények, elsősorban a $F$. japonica és a $F$. $\times$ bohemica, kisebb mértékben a $F$. sachalinensis (BALOGH 2004, BAILEY és WisSKIRCHEN 2006). Hasonló a szerepük a meghódított távoli földrészeken is. A $F$. japonica-t például a 19. század végén hurcolták be Észak-Amerikába, Új-Zélandra pedig 1935-ben került (BEERLING et al. 1994, BALOGH 2008).

A Fallopia japonica gyógyászati célú alkalmazása mellett a növénynek számos etnobotanikai felhasználása ismert. A második világháborúban a növény leveleit dohány helyettesítésére használták (BEERLING et al. 1994, BALOGH 2008). Emellett táplálékként is közöltek adatokat a fajról; a Cherokee indiánok leveleit fogyasztották (BARNEY et al. 2006). Fiatal hajtásai salátaként ismertek, ízük a manduláéhoz hasonló; megfőzve a spárgához hasonlóan elkészítve vagy püréként ismert. A rebarbara helyettesítőjeként speciálisan elkészített savanyú szószok kísérőjeként alkalmazzák (BEERLING et al. 1994). Japánban néhány helyen a $F$. sachalinensis fiatal, puha hajtásait is fogyasztják (BALOGH 2008). A növény nagy leveleit melegebb éghajlaton gyümölcsök védelmére használják hőség ellen (Marigo és Pautou 1998, Balogh 2008). A faj ismert a horgászatban is mint csalétek, ezenkívül népszerű volt az ezt telepítő német vadászok körében, mert feltételezték, hogy ízletesebb a vad számára, mint a F. japonica, valamint leshelynek is megfelelőnek tünt a vadászat ideje alatt (BALOGH 2008). 


\section{Gyógyászati jelentőség, alkalmazási lehetőségek}

A Polygonaceae családba tartozó óriáskeserűfüveknek számos gyógyászati felhasználása ismert. Ázsiában égések, epekő, hepatitis, gyulladás és osteomyelitis (csontvelőgyulladás) kezelésére alkalmazzák a növényeket (HROMÁD KovÁ et al. 2010). A hagyományos kínai és japán gyógyászatban a $F$. japonica szárított rizómáit gennyes bőrgyulladás, hepatitis, tumorok, magas vérnyomás, vérzés, tripper, fejkosz, lábgombásodás és magas vérzsírszint gyógyítására használják (BEERLING et al. 1994, BALOGH 2008, SHEN et al. 2011). A növény hivatalosan is szerepel a kínai gyógyszerkönyvben (CHEN et al. 2013): aktív hatóanyagait a kínai gyógyászatban égések kezelésére alkalmazzák, amellyel Molnár (1991) gyógyszerészdoktori disszertációjában foglalkozott részletesebben (BALOGH 2008).

Az óriáskeserűfüvek gyógyszerészeti felhasználása az emodinra és a stilbénekre (rezveratrol, piceatannol és glikozidjaik, piceid, rezveratrolozid) fókuszál (Kovárová et al. 2011). A F. japonica és a F. sachalinensis biológiailag aktív vegyületei közül pl. a rezveratrol rendelkezik antibakteriális és antifungális hatással (Murrell et al. 2011). A rezveratrol, mint természetes forrásokban előforduló polifenol nagy mennyiségben van jelen sok gyümölcsben és zöldségben; kimutatták antimikrobás (CHAN 2002), antioxidáns, gyulladáscsökkentő és rákellenes hatását is (Kovárová et al. 2011). A F. japonicá-ban található rezveratrol emellett patkányokban a koleszterinszintet csökkenti (PARK et al. 2004, BALOGH 2008), az epilepszia ellen alkalmazható karbamazepin koncentrációját pedig növeli ( $\mathrm{CHI}$ et al. 2012). A rezveratrol rákellenes hatását ennél a fajnál is kimutatták (BARNEY et al. 2006). A belőle kivont emodin gátló hatású egy bélparazita szívóféreg, a vérmétely (Schistosoma japonicum) ellen (BALOGH 2008), míg az emodin-8-O-ß-glikozid neuroprotekítv hatással rendelkezik (WANG et al. 2007). A növényt Ázsiában, elsősorban Kínában a rezveratrol gyártására használják (KovÁRovÁ et al. 2010, 2011, FRANTíK et al. 2013), amelyet világszerte árulnak étrend-kiegészítő termékekben (CHEN et al. 2013). A zuzmókban, gombákban és a hajtásos növényekben előforduló emodin gyulladáscsökkentő és rákellenes hatású vegyület (HUANG et al. 2007, HromÁd KOVÁ et al. 2010); jelenlétét a $F$. japonica és $F$. sachalinensis esetében már leírták (KovÁrová et al. 2011). A F. japonica esetében a rizómából izolált piceid lipid- és koleszterinszint-csökkentő hatását magas vérzsírszintű hörcsögökben mutatták ki (Du et al. 2009). A növény vizes kivonata gátolta az iNOS és COX-2 expresszióját (KIM et al. 2007), míg neuroprotektív hatást mutattak ki a növény egyes naftalén- és flaván-származékai esetében (LIU et al. 2015).

További vizsgálat támasztja alá, hogy a F. sachalinensis-ben található flavonoidok a metanolos kivonat magas antioxidáns aktivitásáért felelősek (HROMÁDKOVÁ et al. 2010). A F. japonica gyökerének metanolos kivonata gátolja a 
biofilm képződését fogakon, amely felelős a későbbi fogszuvasodásért (HROMÁDKOVÁ et al. 2010). A növény kivonata aktivitást mutatott baktériumtörzsek és gombák ellen, amely a flavonoid-tartalomnak tulajdonítható, így a növényt hagyományosan különböző fertőző betegségek kezelésére használják (ZHANG et al. 2013). Kimutatták továbbá citotoxikus hatását HeLa sejtvonalakon (EID et al. 2015), valamint egy naftokinon-származék oszteoklasztok kialakulását gátló hatását (CHIOU et al. 2010).

A Fallopia japonica-hoz hasonlóan a $F$. sachalinensis rizómáját is számos betegség kezelésére alkalmazzák, amelyekért elsősorban antrakinon-származékokat tesznek felelőssé (BALOGH 2008). A növény levélkivonata hatásosnak tűnt néhány növényi betegség megfékezésében (HrOMÁDKová et al. 2010, MARIGO és PAUTOU 1998), például alma, begónia, uborka és búza lisztharmat-fertőzése, illetve az édes paprika szürkerothadása ellen is (BALOGH 2008). A F. japonica jelentős allelopátiás potenciállal is rendelkezik (CsIszÁR et al. 2012).

A Fallopia fajok nektárt termelnek (KovÁrová et al. 2011), így például a $F$. japonica kitűnő táplálékforrás méhek számára (BARNEY et al. 2006). A $F$. japonica-t és a $F$. sachalinensis-t takarmányként használják a levelekben található magas fehérjetartalom miatt (MARIgo és PAUTOU 1998). Évekig folytak kísérletek házi- és vadállatok számára történő termesztésükre (BALOGH 2008).

A növények használhatók a nehézfémek által szennyezett talajok mentesítésére, mivel képesek nehézfémeket felhalmozni (MARIgo és PaUtou 1998, BALOGH 2008, KovÁrová et al. 2011). A F. japonica lehetséges felhasználását, mint nehézfém-megkötő Európában és Japánban is vizsgálták, mivel leveleiben és gyökereiben (föként a sejtfalakban) képes például rezet, cinket és kadmiumot akkumulálni (BARNEY et al. 2006). A Fallopia fajokat továbbá alkalmazták folyópartok, homokbuckák megerősítésére, valamint meddőhányók stabilizálására is (BALOGH 2008).

$\mathrm{Az}$ óriáskeserüfüvek magas növekedési rátájuk és biomassza-produkciójuk miatt energianövényként hasznosíthatók, mivel teljes fütőértékük a fás növényekéhez hasonló (KovÁrová et al. 2011).

\section{Irodalomjegyzék}

Aguilera A. G., Alpert P., Dukes J. S., Harrington R. 2010: Impacts of the invasive plant Fallopia japonica (Houtt.) on plant communities and ecosystem processes. Biological Invasions 12(5): 1243-1252. http://dx.doi.org/10.1007/s10530-009-9543-z

BAILEY J. P. 2003: Japanese knotweed s.l. at home and abroad. In: CHILD L., BROCK J., BRUNDU G., Prach K., Pyšex P., Wade P. M., Williamson M. (eds.) Plant invasions: Species ecology and ecosystem management. Backhuys Publishers, Leiden, pp. 183-196.

BAiley J., Wiss KirChen R. 2006: The distribution and origins of Fallopia $\times$ bohemica (Polygonaceae) in Europe. Nordic Journal of Botany 24(2): 173-199.

http://dx.doi.org/10.1111/j.1756-1051.2004.tb00832.x 
BALOGH L. 2004: Japánkeserüfü-fajok (Fallopia sectio Reynoutria). In: MiHÁly B., BottA-Dukát Z. (szerk.) Biológiai inváziók Magyarországon: Özönnövények. A KvVM Természetvédelmi Hivatalának tanulmánykötetei 9, Természetbúvár Alapítvány Kiadó, Budapest, pp. 207-253.

BALOGH L. 2008: Japanese, giant and Bohemian knotweed (Fallopia japonica (Houtt.) Ronse Decr., F. sachalinensis (Frdr. Schmidt) Ronse Decr. and F. xbohemica (Chrtek et Chrtková) J. P. Bailey). In: Botta-DukÁt Z., BALOGH L. (eds.) The most important invasive plants in Hungary. Hungarian Academy of Sciences, Institute of Ecology and Botany, Vácrátót, pp. 13-33.

BAlogh L. 2009: Fallopia Adans. (s. 1.) [incl. Bilderdykia Dumort., Reynoutria Houtt., Polygonum sect. Tiniaria Meissner et Pleuropterus (Turcz.) Benth.] - Keserüfü (p. p.), óriáskeserüfü. In: KIRÁLY G. (szerk.) Új magyar füvészkönyv. Magyarország hajtásos növényei. Határozókulcsok. Aggteleki Nemzeti Park Igazgatóság, Jósvafö, pp. 112-113.

BALOGH L. 2012: Cseh óriáskeserüfü (Fallopia × bohemica (Chrtek \& Chrtková) J. P. Bailey), japán óriáskeserüfü (Fallopia japonica (Houtt.) Ronse Decr.), szahalini óriáskeserüfü (Fallopia sachalinensis (F. Schm.) Ronse Decr.). In: Csıszár Á. (szerk.) Inváziós növényfajok Magyarországon. Nyugat-magyarországi Egyetem Kiadó, Sopron, pp. 48-55.

Barney J. N., Tharayil N., DiTommaso A., Bhowmi P. C. 2006: The biology of invasive alien plants in Canada. 5. Polygonum cuspidatum Sieb. \& Zucc. [= Fallopia japonica (Houtt.) Ronse Decr.]. Canadian Journal of Plant Science 86(3): 887-905. http://dx.doi.org/10.4141/P05-170

Beerling D. J., Bailey J. P., Conolly A. P. 1994: Fallopia japonica (Houtt.) Ronse Decraene (Reynoutria japonica Houtt.; Polygonum cuspidatum Sieb. \& Zucc.). Journal of Ecology 82(4): 959-979. http://dx.doi.org/10.2307/2261459

Beerling D. J., Huntley B., Bailey J. P. 1995: Climate and the distribution of Fallopia japonica: use of an introduced species to test the predictive capacity of response surfaces. Journal of Vegetation Science 6(2): 269-282. http://dx.doi.org/10.2307/3236222

Békésiné Kallenberger H., Bencsik T., Farkas Á., Balogh L., Papp N. 2012: A Fallopia sachalinensis és $F$. × bohemica fajok összehasonlító szövettani vizsgálata. In: PAPP N. (szerk.) XIV. Magyar Növényanatómiai Szimpózium, 2012.09.28., Pécs, Program és összefoglalók, pp. 45-46.

BéKési-Kallenberger H., Papp N., Bencsik T., Balogh L., Horváth Gy. 2013: Ethnopharmacological and phytochemical data of Fallopia species. In: MARCulescu A. (ed.) The Vth Symposium of Ethnopharmacology with international participation, 21-23 June 2013, Brasov. Romanian Society of Ethnopharmacology, p. 63.

Bímová K., MANDÁk B., PYŠEK P. 2003: Experimental study of vegetative regeneration in four invasive Reynoutria taxa (Polygonaceae). Plant Ecology 166: 1-11.

http://dx.doi.org/10.1023/A:1023299101998

Borhidi A. 1998: Polygonanae. In: A zárvatermők fejlődéstörténeti rendszertana. Nemzeti Tankönyvkiadó, Budapest, p. 178.

CHAN M. M-Y. 2002: Antimicrobial effect of resveratrol on dermatophytes and bacterial pathogens of the skin. Biochemical Pharmacology 63(2): 99-104. http://dx.doi.org/10.1016/S0006-2952(01)00886-3

Chen H., Tuck T., Ji X., Zhou X., Kelly G., Cuerrier A., Zhang J. 2013: Quality assessment of Japanese knotweed (Fallopia japonica) grown on Prince Edward Island as a source of resveratrol. Journal of Agricultural and Food Chemistry 61(26): 6383-6392. http://dx.doi.org/10.1021/jf4019239

CHI Y. C., LiN S. P., Hou Y. C. 2012: A new herb-drug interaction of Polygonum cuspidatum, a resveratrol-rich nutraceutical, with carbamazepine in rats. Toxicology and Applied Pharmacology 263(3): 315-322. http://dx.doi.org/10.1016/j.taap.2012.07.003 
Chiou W. F., Liao J. F., Huang C. Y., Chen C. C. 2010: 2-Methoxystypandrone represses RANKL-mediated osteoclastogenesis by down-regulating formation of TRAF6-TAK1 signalling complexes. British Journal of Pharmacology 161(2): 321-335.

http://dx.doi.org/10.1111/j.1476-5381.2010.00823.x

Csiszár Á., Korda M., Schmidt D., Šporčić D., Teleki B., Tiborcz V., Zagyvai G., Bartha D. 2012: Néhány inváziós és potenciálisan inváziós neofiton allelopátiás hatásának vizsgálata. Botanikai Közlemények 99(1-2): 159-171.

Du J., Sun L-N., Xing W-W., Huang B-K., Jia M., Wu J-Z., Zhang H., Qin L-P. 2009: Lipidlowering effects of polydatin from Polygonum cuspidatum in hyperlipidemic hamsters. Phytomedicine 16: 652-658. http://dx.doi.org/10.1016/j.phymed.2008.10.001

Eid S. Y., El-Readi M. Z., Ashour M. L., Wink M. 2015: Fallopia japonica, a natural modulator, can overcome multidrug resistance in cancer cells. Evidence-Based Complementary and Alternative Medicine, Article ID 868424, 1-8. http://dx.doi.org/10.1155/2015/868424

Fan P., Marston A., Hay A. E., Hostettmann K. 2009: Rapid separation of three glucosylated resveratrol analogues from the invasive plant Polygonum cuspidatum by high-speed countercurrent chromatography. Journal of Separation Science 32 (17): 2979-2984.

http://dx.doi.org/10.1002/jssc.200900057

FormAn J., KesSeli R. V. 2003: Sexual reproduction in the invasive species Fallopia japonica (Polygonaceae). American Journal of Botany 90: 586-592. http://dx.doi.org/10.3732/ajb.90.4.586

Frantí K T., Kovářová M, Koblihová H., BartưŇKová K., NÝvltová Z., Vosát Ka M. 2013: Production of medically valuable stilbenes and emodin in knotweed. Industrial Crops and Products 50: 237-243. http://dx.doi.org/10.1016/j.indcrop.2013.07.017

Gerber E., Krebs C., Murrella C., Morettib M., Rocklinc R., Schaffnera U. 2008: Exotic invasive knotweeds (Fallopia spp.) negatively affect native plant and invertebrate assemblages in European riparian habitats. Biological Conservation 141: 646-654. http://dx.doi.org/10.1016/j.biocon.2007.12.009

Grimbsby J. L., Tsirelson D., Gammon M. A., Kesseli R. 2007: Genetic diversity and clonal vs. sexual reproduction in Fallopia spp. (Polygonaceae). American Journal of Botany 94 (6): 957-964. http://dx.doi.org/10.3732/ajb.94.6.957

HAJZEROVÁ L., REIF J. 2014: Bird species richness and abundance in riparian vegetation invaded by exotic Reynoutria spp. Biologia 69: 247-253. http://dx.doi.org/10.2478/s11756-013-0296-x

Hegi G. 1910: Illustrierte Flora von Mittel-Europa. Munich, 3: 189-190.

Hollingsworth M. L., BAILEY J. P. 2000: Evidence for massive clonal growth in the invasive weed Fallopia japonica (Japanese Knotweed). Botanical Journal of the Linnean Society 133: 463-472. http://dx.doi.org/10.1111/j.1095-8339.2000.tb01589.x

Hromád ková Z., Hirsch J., Ebringerová A. 2010: Chemical evaluation of Fallopia species leaves and antioxidant properties of their non-cellulosic polysaccharides. Chemical Papers 64 (5): 663-672. http://dx.doi.org/10.2478/s11696-010-0054-2

Huang Q., Lu G., Shen H-M., Chung M. C. M., Ong C. N. 2007: Anti-cancer properties of anthraquinones from rhubarb. Medicinal Research Reviews 27(5): 609-630. http://dx.doi.org/10.1002/med.20094

KIM J. Y., PARK C.-W. 2000: Morphological and chromosomal variation in Fallopia section Reynoutria (Polygonaceae) in Korea. Brittonia 52(1): 34-48. http://dx.doi.org/10.2307/2666492

Kim K. W., Ha K. T., Park C. S., Jin U. H., Chang H. W., Lee I. S., Kim C. H. 2007: Polygonum cuspidatum, compared with baicalin and berberine, inhibits inducible nitric oxide synthase and cyclooxygenase-2 gene expressions in RAW 264.7 macrophages. Vascular Pharmacology 47(2-3): 99-107. http://dx.doi.org/10.1016/j.vph.2007.04.007 
Kovárová M., Bartůnková K., Frantík T., Koblihová H., Prchalová K., Vosátka M. 2010: Factors influencing the production of stilbenes by the knotweed, Reynoutria $\times$ bohemica. BMC Plant Biology 10: 19. http://dx.doi.org/10.1186/1471-2229-10-19

Kovárová M., Frantík T., Koblihová H., Bart ŮŇKová K., NÝvltová Z.,Vosát Ka M. 2011: Effect of clone selection, nitrogen supply, leaf damage and mycorrhizal fungi on stilbene and emodin production in knotweed. BMC Plant Biology 11: 98. http://dx.doi.org/10.1186/1471-2229-11-98

LiU F., Li F. S., Feng Z. M., YANG Y. N., Jiang J. S., Li L., Zhang P. C. 2015: Neuroprotective naphthalene and flavan derivatives from Polygonum cuspidatum. Phytochemistry 110: 150-159. http://dx.doi.org/10.1016/j.phytochem.2014.12.007

Marigo G., Pautou G. 1998: Phenology, growth and ecophysiological characteristics of Fallopia sachalinensis. Journal of Vegetation Science 9(3): 379-386. http://dx.doi.org/10.2307/3237102

Mizutani, J. 1996: Plant ecochemicals which may play important roles in complex interactions between higher plants. FWCA Book Abstr., p. 161.

MolnÁr B. 1991: A japánkeserüfü (Reynoutria japonica Houtt.) fitokémiai vizsgálata. Gyógyszerészdoktori értekezés. Janus Pannonius Tudományegyetem, Pécs, 69 p.

MolnáR V. A. 2009: Növények és emberek. Egy szeretetre méltó tudomány története. Kitaibel Kiadó, Biatorbágy, 200 pp.

Murai Y, Setoguchi H, Kitajima J, Iwashina T. 2015: Altitudinal variation of flavonoid content in the leaves of Fallopia japonica and the needles of Larix kaempferi on Mt. Fuji. Natural Product Communications 10(3): 407-11.

Murrell C., Gerber E., Krebs C., Parepa M., Schaffner U., Bossdorf O. 2011: Invasive knotweed affects native plants through allelopathy. American Journal of Botany 98(1): 38-43. http://dx.doi.org/10.3732/ajb.1000135

PAR K C. S., LeE Y. C., Kim J. D., Kim H. M., Kim C. H. 2004: Inhibitory effects of Polygonum cuspidatum water extract (PCWE) and its component resveratrol [correction of rasveratrol] on acyl-coenzyme A-cholesterol acyltransferase activity for cholesteryl ester synthesis in HepG2 cells. Vascular Pharmacology 40(6): 279-84. http://dx.doi.org/10.1016/j.vph.2004.01.003

PENG W., QIN R., Li X., ZHOU H. 2013: Botany, phytochemistry, pharmacology, and potential application of Polygonum cuspidatum Sieb.et Zucc.: a review. Journal of Ethnopharmacology 148(3): 729-745. http://dx.doi.org/10.1016/j.jep.2013.05.007

Qian G., Leung S. Y., Lu G., LeUnG K. S. 2008: Optimization and validation of a chromatographic method for the simultaneous quantification of six bioactive compounds in Rhizoma et Radix Polygoni Cuspidati. Journal of Pharmacy and Pharmacology 60(1): 107-113. http://dx.doi.org/10.1211/jpp.60.1.0014

Shen M-Y., Liu Y-J., Don M-J., Liu H-Y., Chen Z-W., Mettling C., Corbeau P., Chiang C-K., Jang Y-S., Li T-H., Young P., Chang C. L. T., Lin Y-L., Yang W-C. 2011: Combined phytochemistry and chemotaxis assays for identification and mechanistic analysis of antiinflammatory phytochemicals in Fallopia japonica. PLoS ONE 6(11): e27480. http://dx.doi.org/10.1371/journal.pone.0027480

Szabó, L. Gy. 1997: Allelopathy - phytochemical potential - life strategy. JPTE, Pécs, 129 pp.

Tiébré M-S., Bizoux J. P., Hardy O. J., Bailey J. P., Mahy G. 2007: Hybridization and morphogenetic variation in the invasive alien Fallopia (Polygonaceae) complex in Belgium. American Journal of Botany 94(11): 1900-1910. http://dx.doi.org/10.3732/ajb.94.11.1900

Tiébré M-S., VAnderhoeven S., SAAD L., MAHy G. 2007: Hybridization and sexual reproduction in the invasive alien Fallopia (Polygonaceae) complex in Belgium. Annals of Botany 99(1): 193-203. http://dx.doi.org/10.1093/aob/mcl242 
Townsend A. 1997: Japanese knotweed: a reputation lost. Arnoldia 57: 13-19.

WANG C., ZHANG D., MA H., LIU J. 2007: Neuroprotective effects of emodin-8-O- $\beta$-D-glucoside in vivo and in vitro. European Journal of Pharmacology 577(1-3): 58-63. http://dx.doi.org/10.1016/j.ejphar.2007.08.033

Yi T., Zhang H., Cai Z. 2007: Analysis of Rhizoma Polygoni Cuspidati by HPLC and HPLC-ESI/ MS. Phytochemical Analysis 18(5): 387-392. http://dx.doi.org/10.1002/pca.993

Zhang L., Ravipati A. S., Koyyalamudi S. R., Jeong S. C., Reddy N., Bartlett J., Smith P. T., De la Cruz M., Monteiro M. C., Melguizo A., Jiménez E., Vicente F. 2013: Anti-fungal and anti-bacterial activities of ethanol extracts of selected traditional Chinese medicinal herbs. Asian Pacific Journal of Tropical Medicine 6(9): 673-681. http://dx.doi.org/10.1016/S1995-7645(13)60117-0

Zimmermann K., Topp W. 1991: Anpassungserscheinungen von Insekten an Neophyten der Gattung Reynoutria (Polygonaceae) in Zentraleuropa. Zoologische Jahrbücher Systematik 118(3-4): 377-390.

\title{
REVIEW
}

\section{Botanical, phytochemical and pharmaceutical characters of Fallopia species adventive in Hungary}

\author{
H. BÉKÉSINÉ KALLENBERGER ${ }^{1}$, Gy. HORVÁTH ${ }^{1}$, L. BALOGH ${ }^{2}$, V. L. BALÁZS ${ }^{3}$ \\ and N. PAPP ${ }^{1 *}$
}

${ }^{1}$ Institute of Pharmacognosy, University of Pécs, H-7624 Pécs, Rókus u. 2.

${ }^{2}$ Department of Natural History, Savaria Museum, H-9701 Szombathely, Kisfaludy S. u. 9. ${ }^{3}$ Institute of Biology, University of Pécs, H-7624 Pécs, Ifjúság u. 6.

*nora4595@gamma.ttk.pte.hu

Accepted: 18 January 2016

Key words: ethnobotany, Fallopia, histology, morphology, phytochemistry, taxonomy.

Fallopia species originate from Asia, but nowadays they are spreading in many areas of the world. In Europe, taxa have been planted in the 19th century as ornamental plants. Among the main phytochemical compounds, tannins, phenolic acids, flavonoids, stibenes (e.g. resveratrol) and anthraquinones (e.g. emodin) can be highlighted, which have several physiological and therapeutical effects, as well. In the traditional Chinese and Japanese medicine, the rhizome of some species is used for hepatitis, high blood pressure, skin injuries and bleeding. Recently, several studies have been carried out on the antibacterial, antifungal, antioxidant, anti-inflammatory, and neuroprotective effect of the plants. In addi- 
tion, preliminary pharmacological data are available on their effect against high cholesterol level and for some cancer types, as well. Some species have metalbinding property and allelopathic effect, while other taxa are studied for their agricultural production to use as fodder. The possible role of Fallopia species as energy plants is based on their high heating value. These results suggest further ecological, phytochemical and pharmacological studies in the future, which draw the attention for the various potential uses of these plants. This work summarizes the botanical (incl. morphological, histological, phytochemical and medicinal), as well as the historical and ethnobotanical features of Fallopia japonica, F. sachalinensis and their hybrid F. $\times$ bohemica. 